\title{
Co-occurrence of dinoflagellate and cyanobacterial harmful algal blooms in southwest Florida coastal waters: dual nutrient ( $\mathrm{N}$ and $\mathrm{P}$ ) input controls
}

\author{
Hans W. Paerl ${ }^{1, *}$, Jennifer J. Joyner ${ }^{1}$, Alan R. Joyner ${ }^{1}$, Karen Arthur ${ }^{2}$, Valerie Paul $^{2}$, \\ Judith M. O'Neil ${ }^{3}$, Cynthia A. Heil ${ }^{4}$ \\ ${ }^{1}$ Institute of Marine Sciences, University of North Carolina at Chapel Hill, 3431 Arendell Street, Morehead City, \\ North Carolina 28557, USA \\ ${ }^{2}$ Smithsonian Marine Station at Fort Pierce, 701 Seaway Drive, Fort Pierce, Florida 34949, USA \\ ${ }^{3}$ Horn Point Laboratory, University of Maryland Center for Environmental Science, Cambridge, Maryland 21613, USA \\ ${ }^{4}$ Fish and Wildlife Institute, Florida Fish and Wildlife Conservation Commission, 100 Eighth Avenue SE, St. Petersburg, \\ Florida 33701-5020, USA
}

\begin{abstract}
During July 2006, 2 distinctly different harmful algal blooms (HABs), one dominated by the pelagic red tide dinoflagellates Karenia spp. and the other by the benthic cyanobacterium Lyngbya majuscula, occurred simultaneously in the coastal embayments surrounding Sanibel and Captiva Islands, Florida, USA. The co-occurring HABs were investigated using in situ bioassays with additions of nitrogen (N) and phosphorus (P) alone and in combination to assess nutrient controls of these 'dueling' toxin-producing species. Photosynthetic, biomass (chlorophyll a), and (in L. majuscula) nitrogen fixation responses to nutrient enrichment were examined over $4 \mathrm{~d}$. Primary productivity in Karenia spp. was consistently stimulated by N additions, while $\mathrm{P}$ additions failed to show stimulation. When added in combination with N, P did not lead to additional stimulation above N alone. Similar patterns of chlorophyll a stimulation were observed. These patterns were observed at $2 \mathrm{~d}$, after which the cells fell out of suspension. Nutrient stimulation of L. majuscula metabolic activities as well as biomass production was smaller and much slower, relative to controls, than responses observed in Karenia spp. After the demise of Karenia spp., L. majuscula was able to continue utilizing subsequent nutrient additions, and it responded most strongly to the $\mathrm{N}+\mathrm{P}$ additions after $4 \mathrm{~d}$. This study confirms previous estuarine and coastal studies that indicated that when non- $\mathrm{N}_{2}$-fixing HABs co-occur with $\mathrm{N}_{2}$-fixing cyanobacterial HAB species, both $\mathrm{N}$ and $\mathrm{P}$ inputs need to be carefully considered and, in all likelihood, controlled.
\end{abstract}

KEY WORDS: Lyngbya $\cdot$ Karenia $\cdot$ Charlotte Harbor $\cdot$ Sanibel and Captiva Islands $\cdot$ Florida $\cdot$ Blooms · Nutrients

Resale or republication not permitted without written consent of the publisher

\section{INTRODUCTION}

Increasing amounts of anthropogenic $\mathrm{N}$ and $\mathrm{P}$ enrichment have accompanied accelerating agricultural and industrial development and urbanization in Florida's coastal watersheds, embayments and keys (Turner et al. 2006, Walsh et al. 2006, Heil et al. 2007, Vargo et al. 2008). Nutrient over-enrichment has been linked to accelerating primary production, or eutrophication, and increased algal bloom frequencies of both harmful and non-harmful phytoplankon species in many coastal regions (Paerl 1987, 1988, Nixon 1995, Boesch et al. 2001, Cloern 2001, Elmgren \& Larsson 2001), including those in Florida (Tomasko et al. 1996, Lapointe 1997, Turner et al. 2006). In Florida and other subtropical regions, increases in nutrient loading have been linked with both diatom (Turner et al. 2006) and cyanobacterial (Glibert et al. 2004) blooms, although blooms of planktonic dinoflagellates and benthic cyanobacteria are also common: the most notorious 
species include the Florida red tide dinoflagellate Karenia brevis (Steidinger et al. 1998, Steidinger 2002, Vargo et al. 2008) and, among the cyanobacteria, the planktonic genus Trichodesmium and the benthic genus Lyngbya. While the origin of these bloomforming taxa (i.e. offshore, nearshore, estuarine) can vary substantially, there is good agreement that when these bloom species encounter nutrient-enriched conditions, growth and bloom intensity of many of these taxa may be enhanced (Paerl 1988, Lapointe 1997, Elmgren \& Larsson 2001, Paerl \& Fulton 2006). Accordingly, there is a great deal of concern about coastal nutrient enrichment associated with rapid rates of coastal development in Florida and elsewhere.

During July 2006, 2 taxonomically and ecologically distinct harmful algal blooms (HABs), one comprised of planktonic Florida red tide dinoflagellates Karenia spp. and the other of the benthic filamentous cyanobacterium Lyngbya majuscula, co-occurred in the coastal embayments of Sanibel and Captiva Islands, on Florida's southwest coast (see Fig. 1). Both genera have been implicated in regional water quality, fisheries habitat, and human health problems (Steidinger et al. 1998, O'Neil \& Dennison 2005, Heil et al. 2007, Paul et al. 2007). Blooms of Karenia spp. are initiated from 18 to $64 \mathrm{~km}$ offshore in the southwest Gulf, and are transported into coastal embayments by currents and tides during the bloom maintenance stage (Steidinger et al. 1998, Walsh et al. 2006). Lyngbya spp. are largely found attached to seagrasses and other benthic substrates, including sand, rocks, oysters, and other benthic flora and fauna. While these species have previously been reported as individual blooms in Florida and other coastal habitats, this was one of the first opportunities to assess their nutrient requirements simultaneously in the same water mass, using in situ nutrient addition bioassays. Despite their contrasting habitat preferences, these HAB species co-occurred, in large part because Karenia spp. was transported into shallow, subtidal waters in which $L$. majuscula flourished as benthic mats and epiphytes. Due to their close proximity, it was likely that both Karenia spp. and L. majuscula derived their nutrients from similar anthropogenic and natural origins. This enabled us to contemporaneously examine nutrient limitation among these HABs.

We utilized an in situ bioassay technique (Paerl \& Bowles 1987, Paerl et al. 1987), previously applied to benthic and planktonic microalgae, to examine photosynthetic and (in the case of Lyngbya majuscula) nitrogen fixation responses together and individually to dissolved inorganic nitrogen (DIN) as nitrate, and phosphorus as phosphate, enrichments. This was done to determine which nutrient(s) were limiting and to what extent these HABs may have been competing for similar nutrient resources. The bioassays were designed to address one central question: Should we be concerned about and hence control only 1 nutrient or both $\mathrm{N}$ and $\mathrm{P}$ ?

\section{MATERIALS AND METHODS}

Water column and benthic HAB samples were collected by boat at Redfish Pass (Fig. 1), a tidal inlet between North Captiva and Captiva Islands $\left(26^{\circ} 32^{\prime} 50.76^{\prime \prime} \mathrm{N}\right.$, $\left.82^{\circ} 11^{\prime} 30.18^{\prime \prime} \mathrm{W}\right)$ on 11 July 2006. Water was collected during an incoming tide. Water column samples, which were discolored by a bloom of Karenia spp. (Fig. 2), were collected in $0.1 \mathrm{~N} \mathrm{HCl}$ precleaned 201 Nalgene polyethylene carboys that were thoroughly rinsed with sample water prior to filling. At the same time and at the same location, Lyngbya majuscula, which occurred as benthic tuft-like mats (Fig. 2), was collected by snorkelers, rinsed with ambient seawater and placed in darkened coolers containing ambient seawater. Both water column and benthic L. majuscula samples were transported to the marine laboratory at the Sanibel-Captiva Conservation Foundation, Sanibel Island, Florida, where they were processed for in situ bioassays within $\sim 2 \mathrm{~h}$ of collection. Care was taken to maintain water temperatures similar to those at the sampling locations and to avoid potentially photo-inhibitory irradiance levels when the samples were brought back to the laboratory.

In situ bioassays. Bioassays were conducted in quintuplicate in $3 \mathrm{l}$ clear polycarbonate wide-mouth jars, which were pre-cleaned with $0.1 \mathrm{~N} \mathrm{HCl}$ and then rinsed twice with deionized water (DI), ensuring nutrient-free conditions prior to adding sample water. One set of jars contained only ambient seawater which was dominated by Karenia spp., and 1 set of jars contained the same ambient seawater and Lyngbya majuscula. Both sets received a full range of nutrient treatments (Table 1). The concentrations and ratios of each species reflected what was in the environment as we did not concentrate the Karenia spp. (i.e. used whole water samples), and the L. majuscula represented what was covering the benthos. Tufts of $L$. majuscula that displaced $10 \mathrm{ml}$ were added to $3 \mathrm{l}$ of water collected at the same site (Figs. $2 \& 3$ ), taking care to use pre-cleaned (rinsed with $0.1 \mathrm{~N} \mathrm{HCl}$ and DI) 41 graduated cylinders and forceps to transfer sample water and L. majuscula tufts, respectively.

All nutrient additions were made with reagent grade (Fisher) chemicals. Nitrogen was added as potassium nitrate $\left(\mathrm{KNO}_{3}\right)$, while $\mathrm{P}$ was added as monobasic potassium phosphate $\left(\mathrm{K}_{2} \mathrm{HPO}_{4}\right)$. Nutrient stock solutions were made up with $18 \mathrm{M} \Omega$ DI in polyethylene (Nalgene) bottles, which were sterilized. Nutrients were 


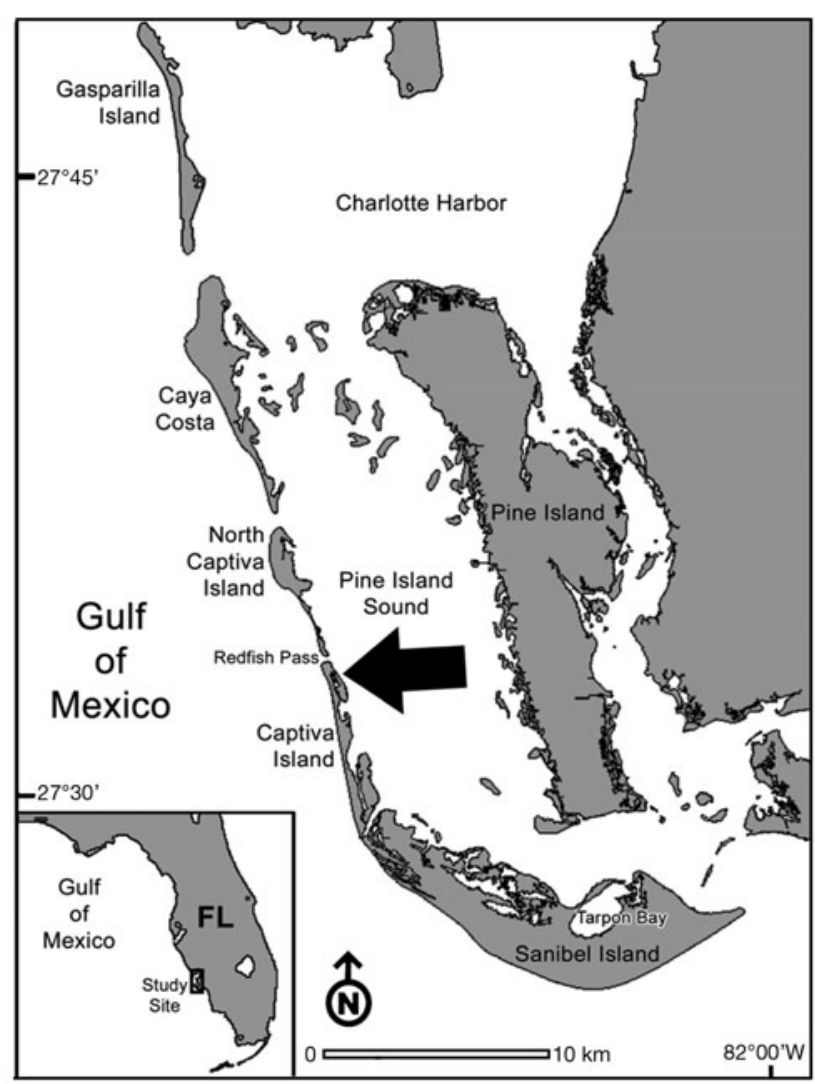

Fig. 1. The Sanibel-Captiva region, Florida, USA, showing location near Redfish Pass (black arrow) where samples were collected. Samples were incubated in situ at the SanibelCaptiva Conservation Foundation Marine Laboratory near Tarpon Bay, Sanibel Island

dispensed to the bioassay containers from stock solutions using sterile pipettes pre-cleaned with DI. Nutrient additions of nitrate and phosphate were made every evening at the concentrations shown in Table 1 to allow time for nutrient uptake before the following morning's primary productivity response measurements were conducted. Determinations of nutrient additions and ratios used in bioassay treatments were based on allochthonous and internally regenerated nutrient inputs and ratios representative of this region (Montgomery et al. 1991, Tomasko et al. 1996, Vargo et al. 2008).

Table 1. Lyngbya majuscula and Karenia spp. Treatments and corresponding nutrient additions for the bioassay incubations

\begin{tabular}{|ll|}
\hline Treatment & Nutrient additions \\
\hline Control & None \\
$\mathrm{N}$ & $10 \mu \mathrm{M} \mathrm{N}-\mathrm{KNO}_{3}$ \\
$\mathrm{P}$ & $5 \mu \mathrm{M} \mathrm{P}-\mathrm{K}_{2} \mathrm{HPO}_{4}$ \\
$\mathrm{~N}+\mathrm{P}$ & $10 \mu \mathrm{M} \mathrm{N}-\mathrm{KNO}_{3}, 5 \mu \mathrm{M} \mathrm{P}-\mathrm{K}_{2} \mathrm{HPO}_{4}$ \\
\hline
\end{tabular}

Following nutrient additions, bioassay vessels were placed in a floating 'corral' that was suspended off the dock at the Sanibel-Captiva Conservation Foundation Marine Laboratory (Fig. 3). Irradiance, temperature and wave conditions were similar to those at the sampling location. A layer of neutral density screening was placed over the corral to reduce incident radiation by $\sim 50 \%$, thereby minimizing photoinhibition during the bioassay incubation period of up to $4 \mathrm{~d}$. Subsamples were collected from each bioassay at the beginning $\left(T_{0}\right)$, Day $2\left(T_{2}, 48 \mathrm{~h}\right)$, and for Lyngbya majuscula only, on Day $4\left(T_{4}, 96 \mathrm{~h}\right)$ after the start of the bioassay.

Algal response parameters included the following: photosynthetic activity, determined with the ${ }^{14} \mathrm{C}$ technique adapted for bioassays (Paerl et al. 1987); nitrogen fixation activity (nitrogenase activity), assessed using the acetylene reduction assay (Paerl 1998); and for Karenia spp., growth based on cell counts and changes in chlorophyll a (chl a) content (Paerl et al. 1987). Although chl a in Lyngbya majuscula does not provide a proxy for growth, it is an indicator of health or robustness of nutrient stores. Photosynthetic and nitrogenase activity were determined on a per-unit biomass ( $g$ dry wt) basis. A wet weight was taken of all of the L. majuscula tufts, and at least 10 tufts were later dried to calculate a wet weight to dry weight conversion based on the linear relationship between wet and dry weights. Wet weights were converted to dry weights using the formula $D=0.3273 \times W-0.0036$, where $W$ is wet weight $(\mathrm{g})$ and $D$ is dry weight $(\mathrm{g})$.

Samples to measure photosynthetic $\mathrm{CO}_{2}$ fixation were collected at $T_{0}$ and from each bioassay container during subsampling periods. For planktonic samples, a $20 \mathrm{ml}$ subsample was withdrawn from each container using a $20 \mathrm{ml}$ syringe and dispensed into a $20 \mathrm{ml}$ glass liquid scintillation vial, which served as the incubation vessel. In the case of Lyngbya majuscula, subsamples of a consistent weight $(0.527 \pm 0.105 \mathrm{~g}$ wet wt; wet weights were converted to dry weights following the experiment using the formula in the previous paragraph) were taken from the bioassay containers and placed in the $20 \mathrm{ml}$ scintillation vials with $20 \mathrm{ml}$ bioassay incubation water. Each scintillation vial received $0.3 \mathrm{ml} \mathrm{NaH}{ }^{14} \mathrm{CO}_{3}(10.6 \mu \mathrm{Ci}$ $\mathrm{ml}^{-1}$; specific activity, $58 \mu \mathrm{Ci} \mu \mathrm{mol}^{-1}$ ). The scintillation vials were then incubated for $\sim 4 \mathrm{~h}$ during mid-day in the bioassay incubation corrals and covered with 1 layer of neutral density screening. One subsample per treatment was placed in a $20 \mathrm{ml}$ darkened vial to account for dark $\mathrm{CO}_{2}$ fixation and/or abiotic uptake. Following the incubation, the samples were filtered onto $25 \mathrm{~mm}$ Whatman $\mathrm{GF} / \mathrm{F}$ filters. The filters were fumed for $4 \mathrm{~h}$ with concentrated $\mathrm{HCl}$ to remove unincorporated ${ }^{14} \mathrm{C}$ and then dried. Once dry, the filters were placed in $7 \mathrm{ml}$ scintillation vials and transported to the Institute of Marine Sciences (Morehead City, North Carolina), where $5 \mathrm{ml}$ of scintil- 

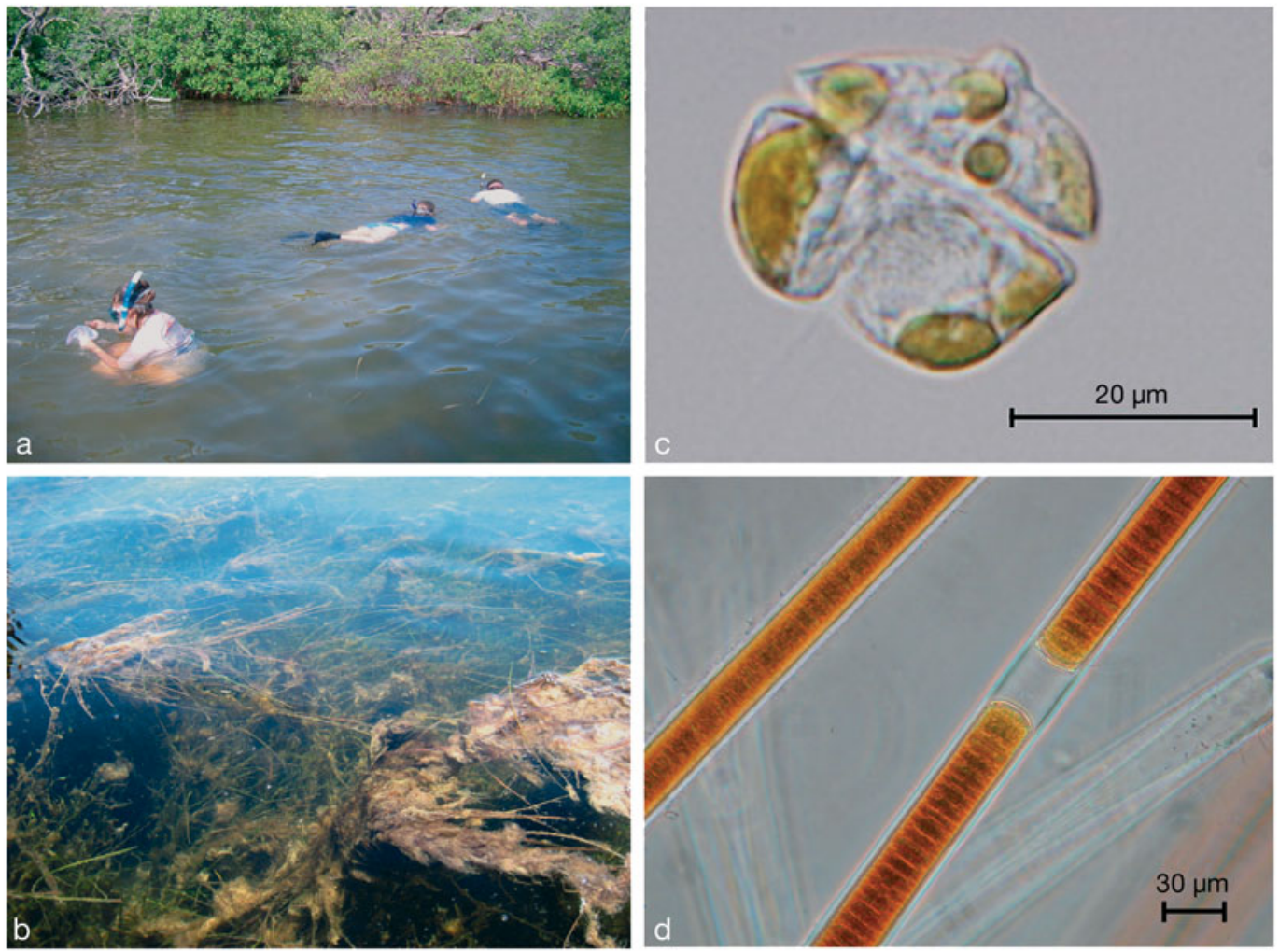

Fig. 2. Karenia spp. and Lyngbya majuscula. Habitats near Redfish Pass. (a) Collection of L. majuscula in waters containing co-occurring blooms of Karenia spp. (the waters being sampled were discolored due to this red tide). (b) L. majuscula smothering a seagrass bed. Also shown are photomicrographs of (c) K. brevis and (d) L. majuscula
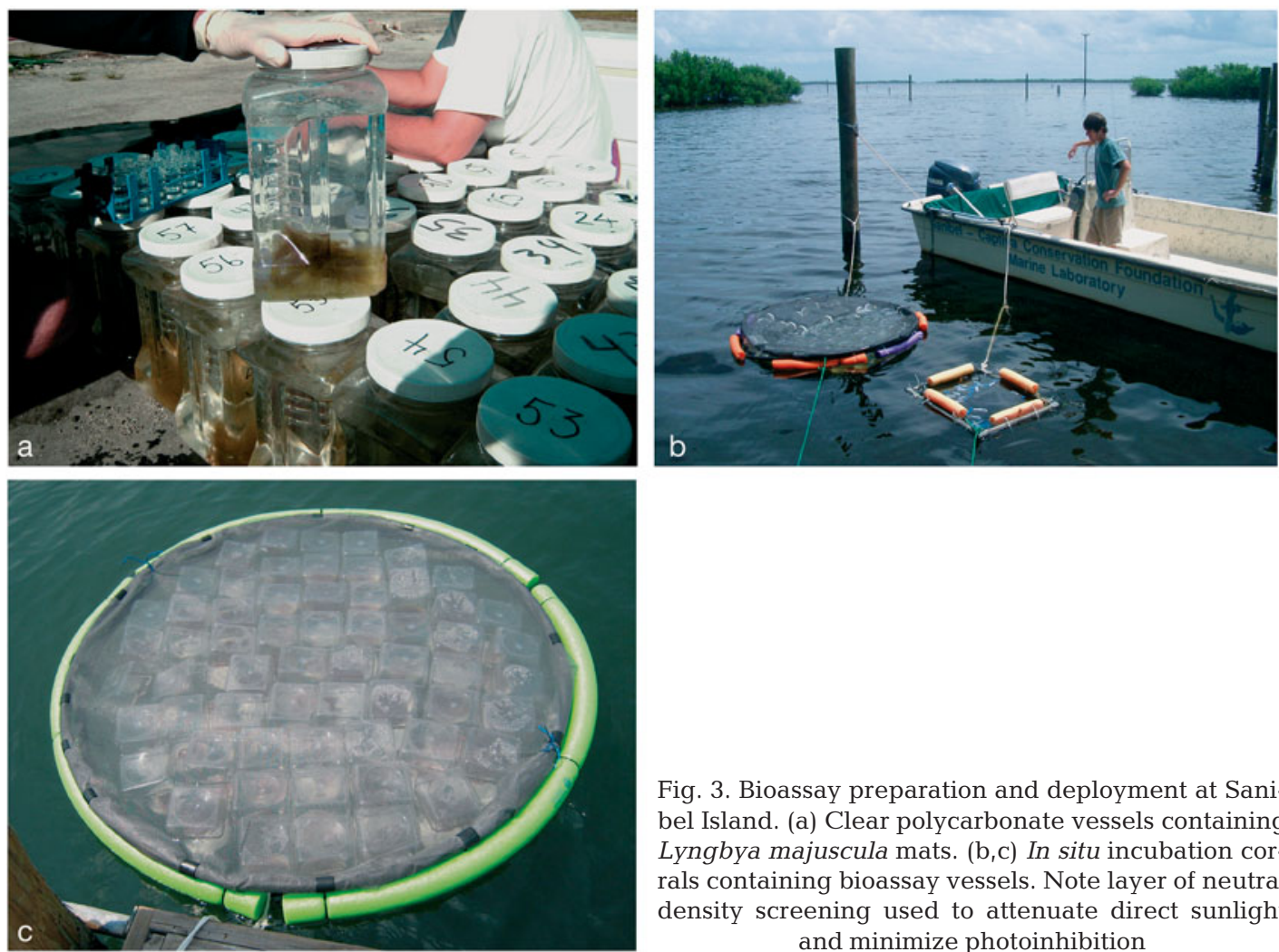

Fig. 3. Bioassay preparation and deployment at Sanibel Island. (a) Clear polycarbonate vessels containing Lyngbya majuscula mats. (b,c) In situ incubation corrals containing bioassay vessels. Note layer of neutral density screening used to attenuate direct sunlight and minimize photoinhibition 
lation cocktail (Cytoscint; ICN) was added to each vial. Vials were sealed and gently shaken, and allowed to sit for $24 \mathrm{~h}$ before being counted. Counts (Beckman Coulter LS 6500 liquid scintillation counter) were converted to disintegrations $\mathrm{min}^{-1}$ using a quench curve based on calibrated $\left({ }^{14} \mathrm{C}\right)$ hexadecane $(\mathrm{NEN})$. The dissolved inorganic carbon content of overlying water was measured by infrared gas absorption analysis (LiCor Model $\mathrm{Li6252)}$. Rates of total $\mathrm{CO}_{2}$ fixation (primary productivity) were calculated using the equation provided in Paerl et al. (1999).

Nitrogenase activity was measured using the acetylene reduction technique (Paerl 1998). On $T_{0}$ (prior to the addition of nutrients), $T_{2}$, and $T_{4}$, pre-weighed tufts of Lyngbya majuscula ( $0.5 \mathrm{~g}$ wet wt, $0.16 \pm 0 \mathrm{~g}$ dry wt) were subsampled from the bioassay and placed into $167 \mathrm{ml}$ glass serum vials, $100 \mathrm{ml}$ bioassay incubation water was added, and the vials were capped with rubber stoppers. From each vial, $20 \mathrm{ml}$ of gas were removed, resulting in a slight vacuum, then $20 \mathrm{ml}$ acetylene gas was bubbled into each of the bottles. Controls consisted of a set of 3 bottles containing only DI, a set containing control treatment water and L. majuscula and no acetylene gas, and a set containing control treatment water and acetylene gas. After $\sim 4 \mathrm{~h}$ incubations in the corrals (covered by 1 layer of neutral density screening), the vials were vigorously shaken for $20 \mathrm{~s}$, and then $4 \mathrm{ml}$ gas from the headspace of each vial was transferred to evacuated $3 \mathrm{ml}$ Vacutainers (Becton Dickinson) for storage and travel back to the Institute of Marine Sciences. Ethylene concentrations were quantified using a Shimadzu model GC9A gas chromatograph with flame ionization detector and a $2 \mathrm{~m}$ Poropak-T column at $80^{\circ} \mathrm{C}$ (Paerl 1998). The DI control values were subtracted from each measurement to account for any ambient ethylene (Paerl 1998).

Samples for Karenia spp. identification and enumeration were taken from the overlying water in the Lyngbya majuscula bioassay at $T_{4}$ and chl a samples were collected at $T_{0}$ and $T_{2}$. Samples for identification were immediately preserved with Lugol's preservative and counted within 4 wk of the experiment. Karenia spp. was identified to the species level where possible according to Steidinger (2008). For the L. majuscula chl a values, $0.5 \mathrm{~g}$ wet wt was frozen in individual aluminum foil packets. For the phytoplankton and Karenia spp. chl a analyses, $50 \mathrm{ml}$ bioassay incubation water was filtered onto Whatman GF/F filters. The filters were blotted dry, wrapped in individual aluminum foil packets and frozen at $-20^{\circ} \mathrm{C}$ in a freezer on site for transportation on blue ice to the laboratory for analysis. In the laboratory, chl a samples were extracted overnight at $-20^{\circ} \mathrm{C}$ using 90:10 acetone:water mix and the concentration was determined by narrow band-pass fluorometry (Welschmeyer 1994) using a Turner TD-700 fluorometer.
Water nutrient analysis samples were collected at $39 \mathrm{~h}$ after the $T_{0}$ dosing. Bioassay water $(100 \mathrm{ml})$ was gently filtered through a pre-combusted Whatman $25 \mathrm{~mm} \mathrm{GF} / \mathrm{F}$ filter, and the filtrate was frozen at $-20^{\circ} \mathrm{C}$ within $6 \mathrm{~h}$ of collection. Filters were also frozen for transport. At the Institute of Marine Sciences, cellular $\mathrm{C}$ and $\mathrm{N}$ were analyzed by fuming the filters with concentrated $\mathrm{HCl}$ to remove excess inorganic $\mathrm{C}$, and then analyzed on a Perkin Elmer Series II CHNS/O 2400 analyzer (Peierls et al. 2003). Total dissolved nitrogen (TDN), $\mathrm{NO}_{2}{ }^{-}+\mathrm{NO}_{3}{ }^{-}, \mathrm{NH}_{4}{ }^{+}$, and $\mathrm{PO}_{4}{ }^{3-}$ were measured from the filtrate on a Lachat Quick-chem 8000 autoanalyzer using standard protocols (Lachat Quik-chem methods 31-107-04-3-B, 31-107-04-1-C, 31-107-06-1-B, and 31-115-01-3-C, respectively).

Statistical analyses. All results are presented as mean \pm SE. Statistical analyses were conducted using Sigma Stat V3.11 (Systat Software) and consisted of a 1-way ANOVA after determining that the data were normally distributed and displayed homogeneity of variances. Where a significant result was obtained for the ANOVA, a Tukey's post hoc pairwise comparison was done to assess differences between treatment groups.

\section{RESULTS}

Both Karenia brevis and Lyngbya majuscula were dominant in planktonic and benthic environments, respectively, at the time of collection and appeared to thrive in bioassay containers for at least $48 \mathrm{~h}$ as assessed at the $T_{2}$ time point. Three different species of Karenia were identified in the bloom and a fourth category, Karenia sp., for cells that could not be identified to species level due to cell orientation in samples. These cells were most likely $K$. brevis or $K$. mikimotoi. The Karenia spp. portion of the bloom was dominated by $K$. brevis (74\%), followed by $K$. mikimotoi (17\%), Karenia sp. (identification to be confirmed) (8\%), and K. seliformis (1\%). Total Karenia spp. cell counts at $T_{4}$ were highly variable, making it difficult to ascertain a nutrient treatment effect, although the highest average Karenia spp. cell counts were observed in the $\mathrm{N}+\mathrm{P}$ treatment (Fig. 4). The incubation comprising Karenia spp. alone was terminated after $3 \mathrm{~d}$ (following $72 \mathrm{~h}$ incubation) because the dinoflagellates began to fall out of suspension. The L. majuscula bioassay was continued for $4 \mathrm{~d}\left(T_{4}\right)$.

During the bioassays, the HAB species took up all soluble $\mathrm{N}$ and $\mathrm{P}$ nutrients in the water column of unenriched control samples, and treatments with nutrient additions had sufficient concentrations to ensure that the organisms were not $\mathrm{N}$ - or P-limited as there were excess nutrients in the water column $39 \mathrm{~h}$ after nutrient additions (Fig. 5). At $T_{2}$, both species appeared to be 
healthy, as they were photosynthetically fixing $\mathrm{CO}_{2}$ (Fig. 6), and Lyngbya majuscula was fixing nitrogen (data not shown). At $T_{2}$, Karenia spp. in both the L. majuscula incubation water and the bioassays of Karenia spp. incubated alone exhibited nitrogen stimulation of primary productivity as $\mathrm{CO}_{2}$ fixation $(\mathrm{p}=$ 0.008 and $\mathrm{p}<0.001$, respectively; Fig. 6A) and a similar trend was observed in biomass as chl a concentration, although this was not statistically significant $(\mathrm{p}=$ 0.074 and $p=0.598$, respectively; Fig. 6B). In contrast to what was observed for Karenia spp. at $T_{2}, L$. majuscula did not show any nutrient treatment effects in terms of productivity or in terms of chl a concentration relative to controls ( $p=0.963$ and $p=0.061$, respectively; Fig. 6), but at $T_{4}$ after the Karenia spp. were observed to fall out of suspension, productivity in the L. majuscula bioassay increased in the $\mathrm{N}+\mathrm{P}$ treatment from an average of $19.6 \mu \mathrm{g} \mathrm{g} \mathrm{g}^{-1} \mathrm{~h}^{-1}$ at $T_{2}$ to $33.6 \mu \mathrm{g} \mathrm{C}$ $\mathrm{g}^{-1} \mathrm{~h}^{-1}$ at $T_{4}$ (Fig. 7). When $\mathrm{N}$ and $\mathrm{P}$ were administered together, this treatment yielded maximum productivity values at $T_{4}(p=0.053)$, which suggested that while the Karenia spp. was in suspension, it effectively utilized N and $\mathrm{P}$ in the presence of $L$. majuscula. After the apparent settling out of suspension of Karenia spp., L. majuscula continued to utilize subsequent nutrient additions.

Nitrogen fixation activity (nitrogenase activity) was confined to samples and treatments that contained Lyngbya majuscula, confirming earlier studies that members of this filamentous, non-heterocystous cyanobacterial genus are capable of $\mathrm{N}_{2}$ fixation (Paerl et al. 1991, Phlips et al. 1991). Rates of nitrogenase activity, measured as acetylene $\left(\mathrm{C}_{2} \mathrm{H}_{2}\right)$ reduction, exhibited very high variability, ranging from 13.4 to $617.2 \mathrm{nmol}_{2} \mathrm{H}_{4} \mathrm{mg}^{-1}$ L. majuscula dry $\mathrm{wt} \mathrm{h}^{-1}$. The highest values for nitrogenase activity occurred on the initial day of sample collection $\left(T_{0}\right)$. At $T_{0}$, values were $71.9 \mathrm{nmol} \mathrm{C}_{2} \mathrm{H}_{4} \mathrm{mg}^{-1}$ L. majuscula dry wt $\mathrm{h}^{-1}$ during the day and $353.4 \mathrm{nmol} \mathrm{C}_{2} \mathrm{H}_{4} \mathrm{mg}^{-1}$ L. majuscula dry wt $\mathrm{h}^{-1}$ at night.

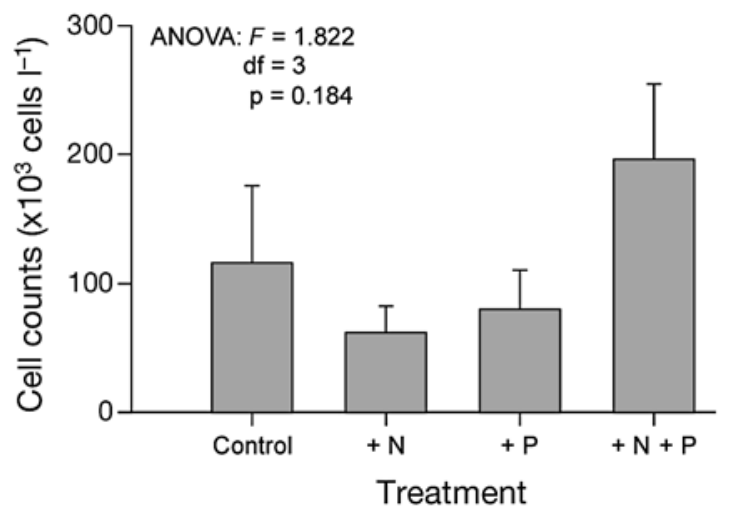

Fig. 4. Karenia spp. Cell counts in bioassay of Karenia spp. incubated alone at $T_{2}$ (48 $\mathrm{h}$ incubation). Error bars represent $+1 \mathrm{SE}$

\section{DISCUSSION}

This opportunistic study of co-occurring HAB species demonstrates that the pelagic non-nitrogen-fixing dinoflagellates Karenia spp. are stimulated by N additions and probably dominate the uptake of latent nutrients over the benthic cyanobacterium Lyngbya majuscula. After the demise of the dinoflagellates in the bioassays there was an increase in L. majuscula productivity in the treatment where both $\mathrm{N}$ and $\mathrm{P}$ were added. The observed $\mathrm{N}$ and $\mathrm{P}$ co-stimulation of L. majuscula primary production demonstrates the potential for these nutrients to individually and jointly enhance growth of this benthic $\mathrm{HAB}$, an observation that has also recently been made for $L$. majuscula populations in Moreton Bay, a subtropical estuarine and coastal embayment in Australia (Albert et al. 2005, Ahern et al. 2007). These findings further illustrate the metabolic flexibility of the genus Lyngbya, freshwater and marine species which are capable of at least partially satisfying their $\mathrm{N}$ requirements through $\mathrm{N}_{2}$ fixation (Paerl et al. 1991, Phlips et al. 1991, Olson et al. 1999, Lundgren et al. 2003, Joyner et al. 2008).

Even though members of this genus are capable of diazotrophy, they are also capable of growth on com-

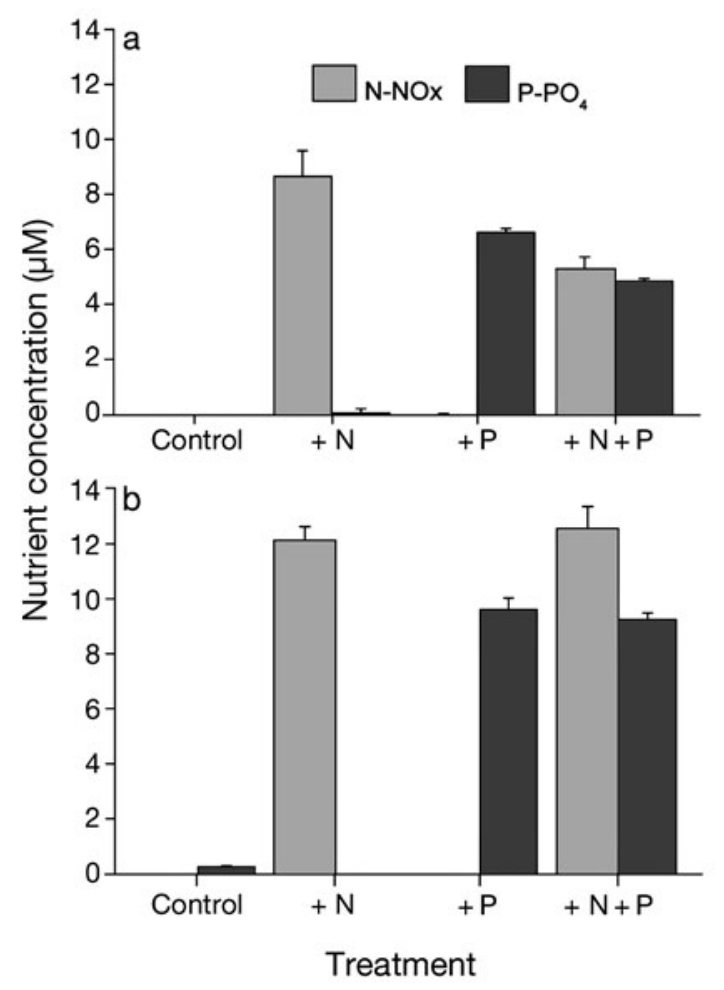

Fig. 5. Karenia spp. and Lyngbya majuscula. Nitrate and phosphate concentrations in water of each bioassay treatment (a: L. majuscula; b: Karenia spp.) at $T_{2}$ ( $48 \mathrm{~h}$ incubation). Error bars represent $+1 \mathrm{SE}$ 


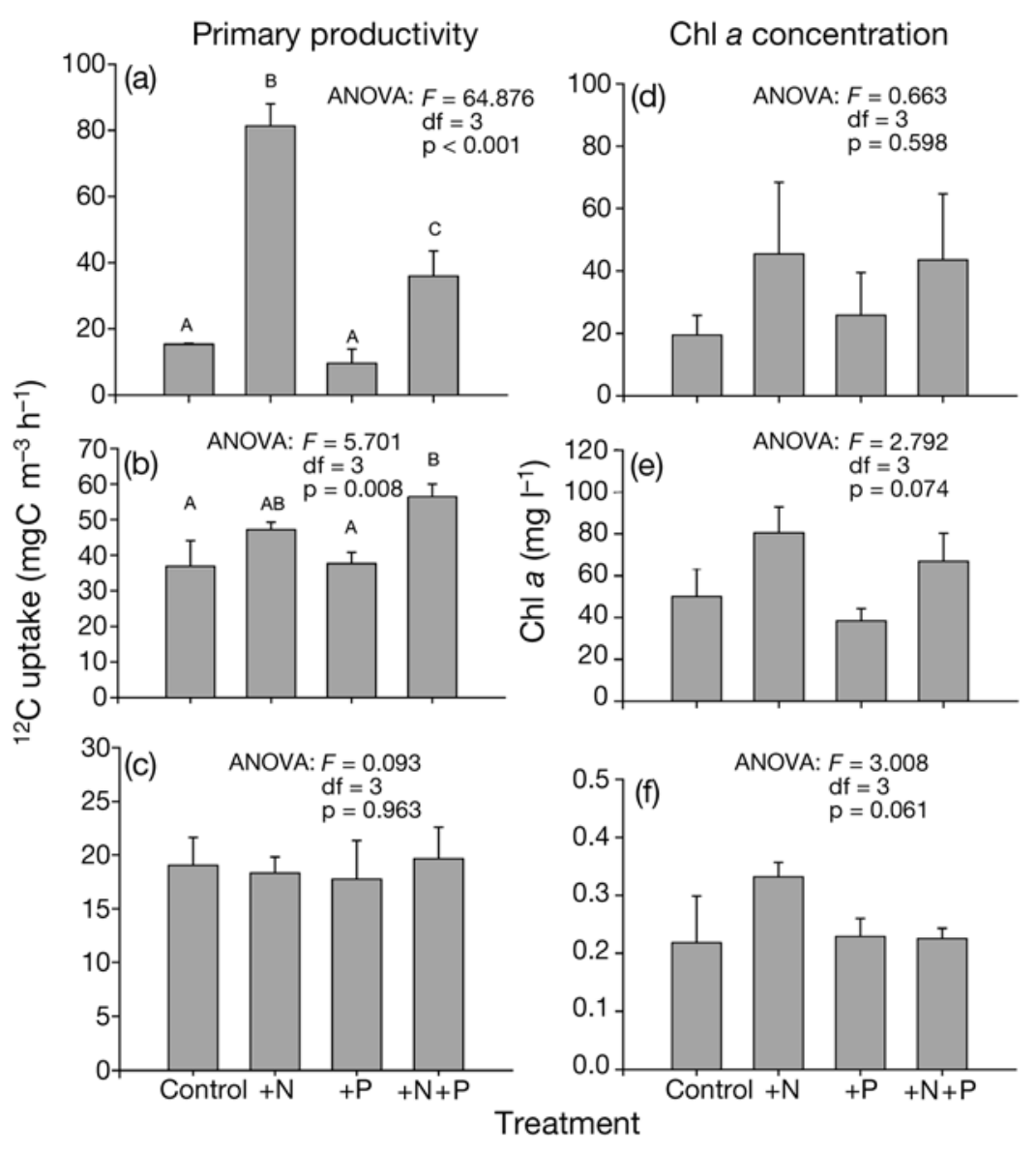

Fig. 6. Karenia spp. and Lyngbya majuscula. Mean (a-c) primary productivity and $(\mathrm{d}-\mathrm{f}) \mathrm{chl}$ a concentrations taken at $T_{2}$ (48 $\mathrm{h}$ incubation) for (a,d) Karenia spp. incubated alone, (b,e) L. majuscula bioassay incubation water containing Karenia spp., and (c,f) L. majuscula. Error bars represent +1 SE. Letters above error bars represent statistically different groups based on Tukey's post hoc pairwise comparisons

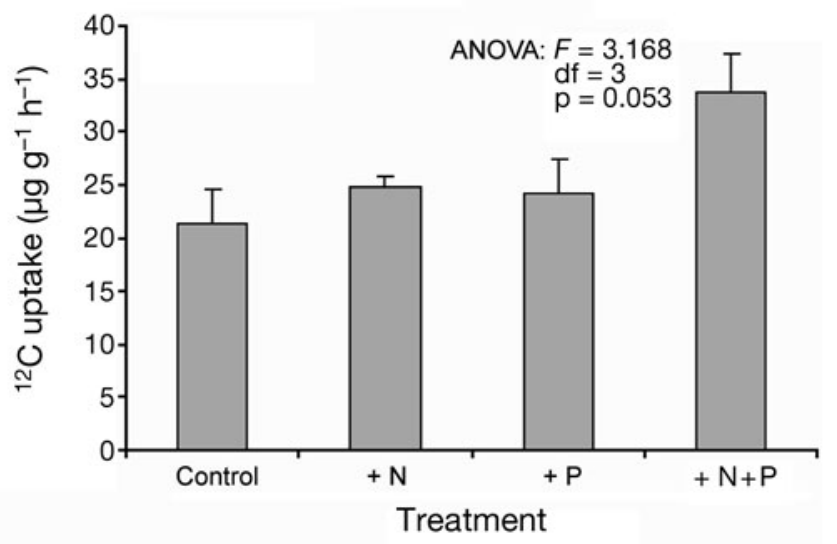

Fig. 7. Lyngbya majuscula. Primary productivity represented as ${ }^{12} \mathrm{C}$ uptake in $L$. majuscula bioassay at $T_{4}$ (96 $\mathrm{h}$ incubation) after daily additions of nitrate $(\mathrm{N})$, phosphate $(\mathrm{P})$ and both $\mathrm{N}$ and P. Error bars represent +1 SE $(n=5)$ bined $\mathrm{N}$, when it is available (Ahern et al. 2007). Freshwater studies on the benthic/ planktonic species Lyngbya birgei and L. wollei have shown that these potential diazotrophs exhibit opportunism when they encounter Nenriched conditions, by effectively utilizing available $\mathrm{N}$ sources to stimulate growth and bloom potential (Beer et al. 1986, Yin et al. 1997, Cowell \& Dawes 2004). For example, riverine, lake, and spring environments that are experiencing $\mathrm{N}$ enrichment from urban, agricultural, and industrial sources have shown a dramatic upsurge in $L$. birgei and L. wollei blooms that can accumulate as nuisance surface scums fouling beaches, choking macrophyte beds, and promoting bottom-water hypoxia (Speziale \& Dyck 1992, Cowell \& Botts 1994). Similarly, in estuarine and coastal marine environments experiencing anthropogenic $\mathrm{N}$ and $\mathrm{P}$ enrichment, opportunistic Lyngbya species have become increasingly widespread and dominant as benthic epilithic and epiphytic blooms (Lapointe 1997, Paul et al. 2005, Paerl \& Fulton 2006).

Nutrient stimulation of Lyngbya majuscula primary productivity was consistently lower and much slower, relative to controls, than responses observed in Karenia spp. In part, the less profound stimulatory response in L. majuscula may have been a reflection of the inherently slower growth rates and doubling times for this benthic cyanobacterium (and filamentous cyanobacteria in general), when compared to published doubling times for diatoms, cryptophytes, and other representative eukaryotic phytoplankton taxa (Pinckney et al. 1999, Reynolds 2006). Karenia brevis has a maximum growth rate of $\sim 0.3 \mathrm{~d}^{-1}$ (Shanley \& Vargo 1993, Magaña \& Villareal 2006), which, although slow compared with other microalgae, is still faster than Lyngbya spp. (Kuffner \& Paul 2001). Similar relative differences in comparative growth responses (cyanobacteria vs. eukaryotes) have been observed in estuarine nutrient addition bioassays (Paerl 1987, Pinckney et al. 1997).

Rates of $\mathrm{CO}_{2}$ fixation observed in bioassays were much higher than typically reported for the Charlotte Harbor estuary (e.g. $9.3 \pm 4 \mathrm{mg} \mathrm{C} \mathrm{m}^{-3} \mathrm{~h}^{-1}$, Turner et al. 2006), although they fall within the range reported for coastal Karenia brevis blooms (19.2 to $127.3 \mathrm{mg} \mathrm{C} \mathrm{m}^{-3}$ $\mathrm{h}^{-1}$, Heil et al. 2004). Primary productivity in water col- 
umn samples dominated by Karenia spp. was strongly and consistently stimulated by $\mathrm{N}$ additions, while $\mathrm{P}$ additions failed to show stimulation (Fig. 6), which is consistent with earlier observations of $\mathrm{N}$ limitation of phytoplankton in bioassays in this estuary (McPherson et al. 1990, Montgomery et al. 1991, Heil et al. 2007). When added in combination with $\mathrm{N}, \mathrm{P}$ did not lead to additional stimulation above that with $\mathrm{N}$ alone (Fig. 6). Similar patterns of chl a stimulation were observed in water column samples, with maximum stimulation taking place in response to the higher level of $\mathrm{N}$ enrichment (Fig. 6). Overall, Karenia spp. primary productivity and biomass production were controlled by $\mathrm{N}$ availability, as has been reported for other Karenia spp. blooms (Heil et al. 2001).

Expanding agricultural, urban, and industrial activities in the coastal zone are responsible for both increased $\mathrm{N}$ and P enrichment (Boesch et al. 2001), although in southwest Florida, these patterns are complicated by natural $\mathrm{P}$ enrichment resulting from the Meiocene Hawthorn phosphatic deposits in central west Florida. Phosphorus enrichment is capable of selectively stimulating $\mathrm{N}_{2}$-fixing cyanobacterial blooms in coastal regions (cf. Elmgren \& Larsson 2001, Paerl \& Fulton 2006), which has also been hypothesized for areas dominated by benthic Lyngbya spp. populations (Elmetri \& Bell 2004). The observed N and P costimulation of coastal L. majuscula populations in Florida and elsewhere (Ahern et al. 2007) raises concern that $\mathrm{P}$ over-enrichment in these waters plays a role in expansion of this HAB in addition to the wellestablished link between $\mathrm{N}$ loading and coastal eutrophication (Ryther \& Dunstan 1971, Paerl 1997, Boesch et al. 2001).

This region of southwest coastal Florida lies at the transition zone between strong $\mathrm{N}$ limitation (from Tampa to Sanibel) and potential P limitation due to DIN inputs from the Caloosahatchee River and dissolved organic nitrogen (DON) inputs from the Everglades (Heil et al. 2007). Heil et al. (2007) speculated that the occurrence of Karenia spp. blooms in this transition region may be due to its ability to utilize DON in a DIN-limited environment. The ability of Lyngbya spp. to 'switch hit' between utilizing exogenous $\mathrm{N}$ compounds (when available) and the vast reservoir of dissolved atmospheric $\mathrm{N}_{2}$ when exogenous combined $\mathrm{N}$ supplies are unavailable and $\mathrm{P}$ is sufficient to support the $\mathrm{N}_{2}$ fixing process suggests that $L$. majuscula may be utilizing a similar strategy, only relying on utilization of gaseous $\mathrm{N}$ via $\mathrm{N}_{2}$ fixation rather than DON uptake.

In addition to clearly benefiting from dissolved inorganic $\mathrm{P}$ inputs to sustain its $\mathrm{N}_{2}$-fixing potential, benthic HABs like Lyngbya majuscula may also benefit from particulate $\mathrm{P}$ inputs, originating from either riverine (terrigenous) or oceanic sources, or possibly dissolved organic $\mathrm{P}$, which is present in significant concentrations in this region (Heil et al. 2007). These P sources, while perhaps not immediately bioavailable, may accumulate in the benthic mats and tufts that L. majuscula produces (Fig. 2) or be available via enzymatic hydrolysis (Al-Shehri 2006). Over time scales longer than the bioassay period $(<1 \mathrm{wk})$, particulate (and perhaps dissolved organic) $\mathrm{P}$ sources may at least in part be solubilized and converted to dissolved inorganic $\mathrm{P}$ by low oxygen microenvironments known to periodically occur in these microphytobenthic environments (Sundbäck et al. 1991, Paerl \& Pinckney 1996, Watkinson et al. 2005). In this manner, mats and tufts can 'trap' potentially biologically available sources of $\mathrm{P}$ to support long-term growth and $\mathrm{N}_{2}$ fixation needs.

In general, Karenia spp. demonstrated a strong need for additional exogenous $\mathrm{N}$ supplies, while Lyngbya majuscula revealed flexibility in meeting its $\mathrm{N}$ requirements, either via use of exogenous $\mathrm{N}$ or $\mathrm{N}_{2}$ fixation, while benefiting from exogenous $\mathrm{N}$ and $\mathrm{P}$ inputs. These findings, while indicating differential limiting nutrient requirements, also demonstrate niche specificity and avoidance of competition for similar nitrogen resources to support growth and bloom formation among these HABs. It appears that based on its strong response to $\mathrm{N}$ inputs, Karenia spp. may be able to take advantage of episodic pulsed inputs of $\mathrm{N}$ from various sources such as rainfall, runoff events, and fish kills (Vargo et al. 2008, Walsh et al. in press) or from $\mathrm{N}_{2}$ fixation-derived DON from nearby co-occurring cyanobacterial blooms such as Trichodesmium spp. (Lenes et al. 2001, Mulholland et al. 2004, 2006, Walsh et al. in press), or perhaps from $L$. majuscula in inshore environments.

Lyngbya majuscula, on the other hand, can also proceed in a more 'slow and steady' mode of satisfying its $\mathrm{N}$ needs, since it can at least partially supplement these needs through $\mathrm{N}_{2}$ fixation. Conversely, Karenia spp. do not appear to have a problem accessing $\mathrm{P}$ to maintain their growth requirements, at least not during the time scale of bioassays (days to a week), while L. majuscula demonstrates a stronger demand for external P inputs (Kuffner \& Paul 2001), most likely to support its $\mathrm{N}_{2}$-fixing capabilities. Over time scales exceeding what we were able to capture with the bioassays, requirements for $\mathrm{P}$ for $L$. majuscula may be met by solubilization of particulate and organic $\mathrm{P}$ sources trapped in mats and tufts, as well as fluxes of $\mathrm{P}$ from the sediments (Watkinson et al. 2005). In any event, these HABs appear to be individually wellpoised for taking advantage of nutrient inputs occurring as a result of anthropogenic activities and/or climatic perturbations such as storms and resultant runoff events. 


\section{Case for dual nutrient ( $\mathrm{N}$ and $\mathrm{P}$ ) controls of coastal eutrophication and HABs}

The present study confirms results from a number of other estuarine and coastal studies, namely that when non- $\mathrm{N}_{2}$-fixing $\mathrm{HABs}$ co-occur with $\mathrm{N}_{2}$-fixing cyanobacterial HAB species, both $\mathrm{N}$ and $\mathrm{P}$ inputs need to be carefully considered and, in all likelihood, controlled. In this regard, it is important to consider potential scenarios like the one encountered in the present study, where a planktonic HAB may coincide with a benthic $\mathrm{HAB}$, with each species having individualistic nutrient requirements, limitations, and specific physiological means for minimizing and/or circumventing these constraints. When tasked with the job of identifying and controlling nutrient inputs aimed at reducing eutrophication and $\mathrm{HAB}$ potentials along the freshwater-marine and estuarine-coastal continua, managers are continually challenged with having to make the choice of single versus dual nutrient input constraints. As this and other studies point out, it is becoming increasingly obvious that controls on both $\mathrm{N}$ and $\mathrm{P}$ input will be needed for effective long-term control of eutrophication, associated HAB outbreaks, and their ecological, biogeochemical, and human-health impacts (e.g. food-web alterations, hypoxia, toxicity, and loss of biodiversity and fisheries resources).

A parallel example can be drawn from the Baltic Sea region, where Elmgren \& Larsson (2001) showed that effective control of eutrophication and HAB outbreaks must include the consideration of total amounts and ratios of $\mathrm{N}$ and $\mathrm{P}$ discharged to waters along the riverine-fjord-coastal-open sea continuum representing the Baltic Sea ecosystem. Similarly, Paerl et al. (2004) pointed out that single nutrient input reductions, including a P-detergent ban and improved wastewater treatment for P during the 1980s in North Carolina's Neuse River estuary, solved one problem (freshwater harmful cyanobacterial blooms), while exacerbating Nsensitive estuarine dinoflagellate blooms. In that case, parallel $\mathrm{N}$ input reductions were required in addition to $P$ reductions to stem eutrophication and HAB potentials along the entire freshwater-marine continuum. Fisher et al. (1988) noted that high levels of anthropogenic N loading discharged to the upper reaches of Chesapeake Bay during the spring runoff period are a cause of seasonal P co-limitation, and at times exclusive P limitation. Using ship-based bioassays, Sylvan et al. (2006) demonstrated that excessive $\mathrm{N}$ loading, characterizing the past several decades of human activity in the Mississippi River Basin, has led to a periodic P limitation in the receiving coastal waters of the northern Gulf of Mexico, where excessive primary production has been identified as a causative agent for the expansion of bottom-water hypoxia (i.e. the 'Dead Zone'), which threatens the ecological integrity of this vitally important coastal ecosystem. In each case, both $\mathrm{N}$ and $\mathrm{P}$ inputs require reduction in order to counter accelerating eutrophication and minimize HAB outbreaks.

While evidence is mounting that dual nutrient ( $\mathrm{N}$ and P) controls are likely to be the rule rather than the exception for managing coastal eutrophication, HAB occurrences, and proliferation, the good news is that controls of one nutrient often lead to parallel reductions in the other. Tertiary wastewater treatment is one example. Other examples include the creation of wetlands and riparian buffer zones for retaining and processing nutrients from storm water and agricultural (non-point source) runoff, and the use of flashboard risers and other structures to enhance retention and instream processing (i.e. denitrification) of nutrients that target both $\mathrm{N}$ and $\mathrm{P}$.

Based on individual HAB responses as shown here and the need to take a basin-level watershed-receiving waters perspective in which nutrient-eutrophication$\mathrm{HAB}$ interactions are considered along the entire freshwater-marine continuum, we can conclude that single nutrient input controls are largely incomplete and ineffective in addressing the negative impacts and ramifications of increasing levels of anthropogenic nutrient inputs associated with population growth in our coastal regions. A larger-scale vision is needed to address this problem. Understanding the ecophysiological complexities and capabilities of coinciding HABs that may originate in different segments of this continuum is proving to be an essential first step for creating the rationale and setting the thresholds for dual nutrient management strategies in the world's coastal waters.

Acknowledgements. The authors thank R. Bartelson and the staff of the Sanibel-Captiva Conservation Foundation Marine Laboratory for field and technical assistance. C. Ross, K. Rossignol, J. Kwan, L. Spiers, S. Harrison, L. A. Cheshire, and L. Linsmeyer provided invaluable field and/or technical assistance. Funding was provided by the National Oceanic and Atmospheric Administration's Ecology and Oceanography of Harmful Algae Blooms (ECOHAB) program (project NA05NOS4781194) and the National Science Foundation (OCE 0327056, DEB 0452324).

\section{LITERATURE CITED}

Ahern KS, Ahern CR, Udy JW (2007) Nutrient additions generate prolific growth of Lyngbya majuscula (cyanobacteria) in field and bioassay experiments. Harmful Algae 6:134-151

Albert S, O'Neil JM, Udy JW, Ahern KS, O'Sullivan CM, Dennison WC (2005) Blooms of the cyanobacterium Lyngbya majuscula in coastal Queensland, Australia: disparate sites, common factors. Mar Pollut Bull 51:428-437

Al-Shehri AM (2006) Factors affecting alkaline phosphatase activity of the marine cyanobacterium Lyngbya majuscula. J Biol Sci 6:931-935

Beer S, Spencer W, Bowes G (1986) Photosynthesis and 
growth of the filamentous blue-green alga Lyngbya birgei in relation to its environment. J Aquat Plant Manag 24: 61-65

Boesch DF, Burreson E, Dennison W, Houde E and others (2001) Factors in the decline of coastal ecosystems. Science 293:1589-1591

$>$ Cloern JE (2001) Our evolving conceptual model of the coastal eutrophication problem. Mar Ecol Prog Ser 210: 223-253

Cowell BC, Botts PS (1994) Factors influencing the distribution, abundance and growth of Lyngbya wollei in central Florida. Aquat Bot 49:1-17

Cowell BC, Dawes CJ (2004) Growth and nitrate-nitrogen uptake by the cyanobacterium Lyngbya wollei. J Aquat Plant Manag 42:69-71

> Elmetri I, Bell PRF (2004) Effects of phosphorus on the growth and nitrogen fixation rates of Lyngbya majuscula: implications for management in Moreton Bay, Queensland. Mar Ecol Prog Ser 281:27-35

Elmgren R, Larsson U (2001) Nitrogen and the Baltic Sea: managing nitrogen in relation to phosphorus. Sci World J 1(Suppl 2):371-377

> Fisher TR, Harding LW Jr, Stanley DW, Ward LG (1988) Phytoplankton, nutrients, and turbidity in the Chesapeake, Delaware, and Hudson estuaries. Estuar Coast Shelf Sci 27:61-93

Glibert PM, Heil CA, Hollander D, Revilla M, Hoare A, Alexander J, Murasko S (2004) Evidence for dissolved organic nitrogen and phosphorus uptake during a cyanobacterial bloom in Florida Bay. Mar Ecol Prog Ser 280:73-83

Heil CA, Vargo GA, Spence D, Neely MB, Merkt R, Lester K, Walsh JJ (2001) Nutrient stoichiometry of a Gymnodinium breve Davis (Gymnodiniales: Dinophyceae) bloom: What limits blooms in oligotrophic environments? In: Hallegraeff G, Blackburn SI, Bolch CJ, Lewis RL (eds) Harmful algal blooms 2000. Intergovernmental Oceanographic Commission of UNESCO, Paris, p 165-168

Heil CA, Mulholland M, Bronk DA, Bernhardt P, O'Neil JM (2004) Bacterial and size fractionated primary production within a large Karenia brevis bloom on the west Florida shelf. In: Steidinger KA, Landsberg JH, Tomas CR, Vargo GA (eds) Harmful algae 2002. Florida Fish and Wildlife Conservation Commission, Florida Institute of Oceanography, and Intergovernmental Oceanographic Commission of UNESCO, St. Petersburg, FL, p 38-40

Heil CA, Revilla M, Glibert PM, Murasko S, Alexander J (2007) Nutrient quality drives phytoplankton community composition on the southwest Florida shelf. Limnol Oceanogr 52:1067-1078

Joyner JJ, Litaker RW, Paerl HW (2008) Morphological and genetic evidence that the cyanobacterium Lyngbya wollei (Farlow ex Gomont) Speziale and Dyck encompasses at least two species. Appl Environ Microbiol 74:3710-3717

Kuffner IB, Paul VJ (2001) Effects of nitrate, phosphate and iron on the growth of macroalgae and benthic cyanobacteria from Cocos Lagoon, Guam. Mar Ecol Prog Ser 222: 63-72

Lapointe BE (1997) Nutrient thresholds for bottom-up control of macroalgal blooms on coral reefs in Jamaica and southeast Florida. Limnol Oceanogr 42:312-323

Lenes JM, Darrow BP, Cattrall C, Heil CA and others (2001) Iron fertilization and the Trichodesmium response on the west Florida shelf. Limnol Oceanogr 46:1261-1277

Lundgren PK, Bauer K, Lugomela C, Soderback E, Bergman B (2003) Reevaluation of the nitrogen fixation behavior in the marine non-heterocystous cyanobacterium Lyngbya majuscula. J Phycol 39:310-314

Magaña HA, Villareal TA (2006) The effect of environmental factors on the growth rate of Karenia brevis (Davis) G. Hansen and Moestrup. Harmful Algae 5:192-198

McPherson BF, Montgomery RT, Emmons EE (1990) Phytoplankton productivity and biomass in the Charlotte Harbor estuarine system, Florida. Water Resour Bull 26: $787-800$

Montgomery RT, McPherson BF, Emmons EE (1991) Effects of nitrogen and phosphorus additions on phytoplankton productivity and chlorophyll $a$ in a subtropical estuary, Charlotte Harbor, Florida. US Geological Survey WaterResources Investigation Report 91-0477. Florida Department of Environmental Regulation, St. Petersburg, FL

Mulholland MR, Heil CA, Bronk DA, O'Neil JM, Bernhardt P (2004) Does nitrogen regeneration from the $\mathrm{N}_{2}$ fixing cyanobacteria Trichodesmium spp. fuel Karenia brevis blooms in the Gulf of Mexico? In: Steidinger, KA, Landsberg JH, Tomas CR, Vargo GA (eds) Harmful algae 2002. Florida Fish and Wildlife Conservation Commission, Florida Institute of Oceanography, and Intergovernmental Oceanographic Commission of UNESCO, St. Petersburg, FL, p 47-49

Mulholland MR, Bernhardt P, Heil CA, Bronk DA, O'Neil JM (2006) Nitrogen fixation and release of fixed nitrogen by Trichodesmium spp. in the Gulf of Mexico. Limnol Oceanogr 51:1762-1776

Nixon SW (1995) Coastal marine eutrophication: a definition, social causes, and future concerns. Ophelia 41:199-219

> Olson JB, Litaker RW, Paerl HW (1999) Ubiquity of heterotrophic diazotrophs in marine microbial mats. Aquat Microb Ecol 19:29-36

O'Neil JM, Dennison WC (2005) Lyngbya majuscula in southeast Queensland waterways. In: Abal EG, Bunn SE, Dennison WC (eds) Healthy waterways, healthy catchment: making the connection in south east Queensland, Australia. Moreton Bay Waterways and Catchment Partnership, Brisbane, p 119-148

Paerl HW (1987) Dynamics of blue-green algal (Microcystis aeruginosa) blooms in the lower Neuse River, North Carolina: causative factors and potential controls. University of North Carolina Water Resources Research Institute report no. 229, NC State University, Raleigh, NC

Paerl HW (1988) Nuisance phytoplankton blooms in coastal, estuarine, and inland waters. Limnol Oceanogr 33: 823-847

Paerl HW (1997) Coastal eutrophication and harmful algal blooms: importance of atmospheric deposition and groundwater as 'new' nitrogen and other nutrient sources. Limnol Oceanogr 42:1154-1165

Paerl HW (1998) Microbially-mediated nitrogen cycling. In: Burlage R (ed) Techniques in microbial ecology. Oxford University Press, New York, p 3-30

> Paerl HW, Bowles ND (1987) Dilution bioassays: their application to assessments of nutrient limitation in hypereutrophic waters. Hydrobiologia 146:265-273

Paerl HW, Fulton RS III (2006) Ecology of harmful cyanobacteria. In: Granéli E, Turner J (eds) Ecology of harmful marine algae. Springer-Verlag, Berlin, p 95-107

Paerl HW, Pinckney JL (1996) Microbial consortia: their role in aquatic production and biogeochemical cycling. Microb Ecol 31:225-247

Paerl HW, Crocker KM, Prufert LE (1987) Limitation of $\mathrm{N}_{2}$ fixation in coastal marine waters: relative importance of molybdenum, iron, phosphorus and organic matter availability. Limnol Oceanogr 32:525-536

Paerl HW, Prufert LE, Ambrose WW (1991) Contemporaneous 
$\mathrm{N}_{2}$ fixation and oxygenic photosynthesis in the non-heterocystous mat-forming cyanobacterium Lyngbya aestuarii. Appl Environ Microbiol 57:3086-3092

Paerl HW, Willey JD, Go M, Peierls BL, Pinckney JL, Fogel ML (1999) Rainfall stimulation of primary production in western Atlantic Ocean waters: roles of different nitrogen sources and co-limiting nutrients. Mar Ecol Prog Ser 176:205-214

Paerl HW, Valdes LM, Piehler MF, Lebo ME (2004) Solving problems resulting from solutions: the evolution of a dual nutrient management strategy for the eutrophying Neuse River Estuary, North Carolina, USA. Environ Sci Technol 38:3068-3073

Paul VJ, Thacker RW, Banks K, Golubic S (2005) Benthic cyanobacterial bloom impacts the reefs of south Florida (Broward County, USA). Coral Reefs 24:693-697

Paul VJ, Arthur KE, Ritson Williams R, Ross C, Sharp K (2007) Chemical defenses: from compounds to communities. Biol Bull (Woods Hole) 213:226-251

Peierls BL, Christian RR, Paerl HW (2003) Water quality and phytoplankton as indicators of hurricane impacts on a large estuarine ecosystem. Estuaries 26:1329-1343

Phlips EJ, Ihnat J, Conroy M (1991) Nitrogen fixation by the benthic freshwater cyanobacterium Lyngbya wollei. Hydrobiologia 234:59-64

Pinckney JL, Millie DF, Vinyard BT, Paerl HW (1997) Environmental controls of phytoplankton bloom dynamics in the Neuse River Estuary (North Carolina, USA). Can J Fish Aquat Sci 54:2491-2501

Pinckney JL, Paerl HW, Harrington MB (1999) Responses of the phytoplankton community growth rate to nutrient pulses in variable estuarine environments. J Phycol 35: 1455-1463

Reynolds CS (2006) Ecology of phytoplankton (ecology, biodiversity and conservation). Cambridge University Press, Cambridge

Ryther J, Dunstan W (1971) Nitrogen, phosphorus, and eutrophication in the coastal marine environment. Science 171:1008-1017

Shanley E, Vargo GA (1993) Cellular composition, growth, photosynthesis, and respiration rates of Gymnodinum breve under varying light levels. In: Smayda TJ, Shimizu Y (eds) Toxic phytoplankton blooms in the sea. Elsevier, Amsterdam, p 831-836

Speziale BJ, Dyck LA (1992) Lyngbya infestations: comparative taxonomy of Lyngbya wollei comb. nov. (cyanobacteria). J Phycol 28:693-706

Steidinger KA (2002) Red tides and other harmful algal

Editorial responsibility: Katherine Richardson,

Copenhagen, Denmark blooms. In: Bitton G (ed) The encyclopedia of environmental microbiology. Wiley, New York, p 2685-2693

Steidinger KA, Vargo GA, Tester PA, Tomas CR (1998) Bloom dynamics and physiology of Gymnodinium breve with emphasis on the Gulf of Mexico. In: Anderson DM, Cembella AD, Hallegraeff GM (eds) Physiological ecology of harmful algal blooms. Springer, Berlin, p 133-153

Steidinger KA, Wolny JL, Haywood AJ (2008) Identification of Kareninaceae (Dinophyceae) in the Gulf of Mexico. Nova Hedwegia 133:269-284

Sundbäck K, Enoksson V, Granéli W, Pettersson K (1991) Influence of sublittoral microphytobenthos on the oxygen and nutrient flux between sediment and water: a laboratory continuous-flow study. Mar Ecol Prog Ser 74: 263-274

> Sylvan JB, Dortch Q, Nelson DM, Brown AM, Morrison W, Ammerman JW (2006) Phosphorus limits phytoplankton growth on the Louisiana shelf during hypoxia formation. Environ Sci Technol 40:7548-7553

> Tomasko DA, Dawes CJ, Hall MO (1996) The effects of anthropogenic nutrient enrichment on turtle grass (Thalassia testudinum) in Sarasota Bay, Florida. Estuaries 19: 448-456

Turner RE, Rabalais NN, Fry B, Atilla N and others (2006) Paleo-indicators and water quality change in the Charlotte Harbor estuary (Florida). Limnol Oceanogr 51:518-533

- Vargo GA, Heil CA, Fanning KA, Dixon LK and others (2008) Nutrient availability in support of Karenia brevis blooms on the central west Florida shelf: What keeps Karenia blooming? Cont Shelf Res 28:73-98

Walsh JJ, Jolliff JK, Darrow BP, Lenes JM and others (2006) Red tides in the Gulf of Mexico: Where, when and why? J Geophys Res 111:C11003, doi:10.1029/2004JC002813

Walsh JJ, Lenes JM, Jolliff JK, Milroy SP and others (in press) Verification of initial conditions for further coupled biophysical models of toxic red tides of Karenia brevis within the Gulf of Mexico. Harmful Algae

Watkinson AJ, O'Neil JM, Dennison WC (2005) Ecophysiology of the marine cyanobacterium, Lyngbya majuscula (Oscillatoriaceae) in Moreton Bay, Australia. Harmful Algae 4:697-715

Welschmeyer NA (1994) Fluorometric analysis of chlorophyll $a$ in the presence of chlorophyll $b$ and phaeopigments. Limnol Oceanogr 39:1985-1992

> Yin Q, Carmichael WW, Evans WR (1997) Factors influencing growth and toxin production by cultures of the freshwater cyanobacterium Lyngbya wollei Farlow ex Gomont. J Appl Phycol 9:55-63

Submitted: February 11, 2008; Accepted: August 6, 2008 Proofs received from author(s): November 5, 2008 